The Role of Oral Correction in Spanish as a Foreign Language Students' (De)motivation.

Fátima Magdalena Gatón Gabriel

A Scholarly Paper

Submitted in Partial Fulfillment of

Advanced Graduate Certificate in SLS - Spanish Applied Linguistics

Department of Second Language Studies

University of Hawai'i at Mānoa

First Reader: Dr. Marta Gonzalez-Lloret

Second Reader: Dr. Graham Crookes

Spring 2020 


\begin{abstract}
Oral correction is a common element in L2 classes associated with linguistic improvement and (de)motivation. To investigate the relationship between oral feedback, (de)motivation and students' language proficiency, the answers to a questionnaire and the observations of four groups of SFL students with different proficiency were compared. The relationship of feedback as a (de)motivator in the L2, the different (de)motivation factors according to the proficiency and the students' perceptions of the corrections, are discussed, as well as their effect on teaching.
\end{abstract}




\section{The Role of Oral Correction in Spanish as a Foreign Language Students' (De)motivation.}

Motivation in second language (L2) learning is considered as the dynamic desire of an individual to reach an objective. This desire can be present in external (extrinsic) or internal (intrinsic) factors also known as motivators. The area that studies motivation has been developed through the last decades, moment in which the concept of demotivation was presented and defined. Now there is a new interest in how demotivation and demotivators are present in students' L2 learning.

Following Dörnyei's (2005) research, there is a relation between demotivators and students' individual differences, the factors of which are: motivation, personality, language aptitude, cognitive and learning styles, language learning style, anxiety, creativity and self-esteem. In spite of all the researches in this area, the great majority study English as a Second Language (ESL); Ushioda's (1998) study was one of the first to research a language that was not English, in her case she focused on French. Due to this lack of projects focused on a language other than English. There is a need to elaborate research on Spanish as a Foreign Language (SFL) and the relation between motivation, linguistic factors (vocabulary, grammar, syntax) and classroom elements (teacher attitudes, classroom structure and feedback).

This research studies the relationship between the degree of demotivation, the type of teacher error correction, and students' language proficiency. Following Dörnyei's studies, we know that motivation in the classroom is one of the most important elements and, therefore, demotivation can cause student's lack of attention (Dörneyi, 2001). Therefore, the objective is to find out what type of corrective feedback is a bigger demotivator for students' later oral production, 
and if the type of demotivator changes with student's language proficiency. More precisely, the study aims at answering the following research questions: RQ1 - What types of oral corrective feedback really take place in a language class?; RQ2 - What type of oral corrective feedback is considered by students and teachers as the most motivating, demotivating and useful when learning a language?; RQ3 - Is there any relationship between second language proficiency and students' perception of oral corrective feedback?

The research will analyze the characteristics of error correction, to establish its possible role as one of the factors that causes demotivation. For this paper, the concept of error will be used for any mistakes caused by the lack of grammatical or linguistic knowledge that can hinder the transmission of a message between the transmitter and the receiver. The results of the study will offer teachers insight on the effects of feedback and help them modify their correcting style to better attend student's needs according to their level of proficiency.

\section{Literature Review}

\section{Motivation}

According to Dörnyei and Ushioda (2011), motivation is considered a person's willingness to do a particular act, its persistence and the effort put in it. The area of motivation has been researched from the 1960s until today, following the research process a different perspective throughout the years. In the 1960s and 1990s, motivation was analyzed from a socio-psychological perspective; during the 1990s, the idea was raised that motivation was associated with cognitive processes such as memorization and learning; later, at the beginning of the twenty-first century, motivation was defined as something fluid and now researchers are aware of the group dynamic

norms that take place in the motivating process. Following this evolution of the concept of 
motivation, Dörnyei in 2001 offered one of the first definitions of demotivation "demotivation: it concerns various negative influences that cancel out existing motivation" (p. 142). The studies that later analyzed demotivation expanded the definition and came up with the terms demotivator(s) and amotivation. Kikuchi's work (2015) offers a new definition of demotivation "the negative process that pulls learners down" (p.5), in addition to giving consideration to demotivating factors - the sum of internal and external factors that reduce the motivation of certain intentions or actions.

When analyzing motivators, one of the highlighted factors is affectivity. In this area of study, the role of affectivity began to stand out and, since then, numerous works have been done on the interests and beliefs of the student, the different motivations, the ease of language learning, the affective filter (Krashen, 1982), the affective dimension (Arnold, 2000), etc. All of these studies had a clear objective, the improvement of the quality of teaching. It is in this line of research that this study fits, the seek of how oral corrective feedback affects learners' motivation as well as their subsequent oral production.

Specifically, this study is linked to a series of researches on demotivation following Dörnyei’s (2001) studies. After Dörnyei’s research, there was no big changes in the concepts study and definition; however, in 2015 professor Kikuchi offers a new view on demotivation, analyzing with more precision the area of study, the determining factors, and a selection of more in-depth hypothesis on the area of demotivation. The concept of error correction in Spanish is also new when relating it to the students' interests. Barbero Carcedo (2012) analyzed and classified the different types of correction into four types depending on the moment correction takes place and what type of correction is given.

The theoretical framework of this research is mainly informed by works from Dörneyi (2001, 2011), Kikuchi (2015) and Kim and Kim (2013). Barbero Carcedo’s (2012) and Vázquez's 
(2010) ideas on error correction and types of error present in the classroom, have been used to create this study's questionnaire and the observation rubric of this research. Kim and Kim (2013) offers information on the latest researches on demotivation, and the increased importance of these for the field of applied linguistics.

\section{Studies on (de)motivation}

The definitions of motivation define the types of motivations that exist and the undeniable fact that motivation is individual to each person.

In 2001, Dörnyei officially introduced the concept of demotivation in the field of language teaching, "demotivation: it concerns various negative influences that cancel out existing motivation" (Dörnyei, 2001, p. 142)". In other words, demotivation is the reflection of the demotivated student that previously was motivated, and demotivators are seen as the negative elements or factors affecting the student. Three non-demotivating elements are highlighted in this work: 1) distractions, 2) gradual loss of interest, and 3) consideration of learning costs. Any element ceases to be demotivating if it is carried out independently by the student; on the contrary, when someone from outside forces the learning process or forces the learner to change, then these elements would be considered demotivators. Moreover, Dörnyei made a distinction between amotivation and demotivation. Amotivation was considered to be an internal and general element of the individual, while demotivators were considered temporary, as soon as they disappear the student's motivation will increase, and they will feel positive. Finally, Dörnyei (2001) also alludes to the roles that teachers play in demotivation. He states that "The main conclusion we can draw from the studies reviewed above is that demotivation is a salient phenomenon in L2 studies and that teachers have a considerable responsibility in this respect" (p. 155). In other words, the teacher 
plays an important role in a demotivating situation; hereby, this study analyzes the teachers' action of correction and its relation to students' (de)motivation.

However, not only are there extrinsic motivators, but there are also intrinsic ones as our ideal self. Lamb (2011) explored the concept of "possible-selves" as a motivating factor in the students learning process. After establishing a relation between possible-selves, motivation and second language acquisition (SLA), he discovered that part of the motivation to acquire a second language depends on the idea one has of their future-selves. The presence of components focused on attending students' future necessities is a key element for motivation. When students identify themselves as active learners, they feel they become part of the learning community, thus fore they are more motivated (Yong \& Coates, 2016). The different "possible-selves" help motivate students; however, it is important to remember this "selves" is not constant and changes through the years. Dörnyei and Ushioda (2011) define clearly this concept "When we talk about sustained long-term activities such as learning a foreign language, motivation does not remain constant during the course of months, years or even during a single lesson. It ebbs and flows in complex ways in response to various internal and external influences" (p. 6).

Kikuchi’s (2015) considers that Dörnyei’s mention of demotivation being associated with external factors has not been empirically analyzed and defines demotivators as the sum of internal and external factors that reduce the motivation of certain intentions or actions. Kikuchi modifies Dörnyei's definition to better identify the concept of demotivators, since demotivation is only "the negative process that pulls learners down" (Kikuchi, 2015, p.5).

\section{Studies and concepts on corrections and errors}


Following this concept, it is possible to create a list of type or errors, for which Vázquez's (2010) work is used as a reference. The author describes a first general level divided between individual, collective, fossilized and transitory errors. The first type are product of the junction with other languages the learner has studied, these however do not stay over time, they disappear as soon as the students language awareness develops. The collective errors are those made by a group of people that share a series of characteristics, they refer to elements from the studied language that can affect in the creation of learning rules. These collective errors can be categorized as fossilized or transitory. The fossilized errors are those that stay and are cause by studied but wrongly applied language rules. Finally, transitory errors, are not definite and usually are associated with a learning phase.

Vázquez (1999) also presents definition of error, that will be the one used as reference for his research - “incorrección que se explica por carencia de competencias lingüística y comunicativa. Las reglas pertinentes no existen en la interlengua. En ese sentido toda producción basada en reglas no adquiridas es un error (cf. Corder: error vs. mistakes)” (p.132).” However, Vázquez is not the only one that defines the concept of error. Authors as Torijano (2004) define the concept and distinguishes between mistake and lapse. This author states that a mistake is a type of error in which the students alternate between the production of wrong and right messages, all with the same linguistic element. As per lapse, this is considered "desviación debida a una falta de concentración, a un fallo de memoria, al cansancio, etc." (Torijano, 2004, p.23) - a deviation due to lack of concentration, memory failure or tiredness.

Vázquez (1999) offers a series of tips a teacher can follow when correcting, not immediately, the students. The evolution rubric must be clear and concise, and, if possible, created in collaboration with the students. With this rubric, assessment would be faster, and students would 
know how they are being assessed and how to understand the table or rubric. Following the topic of correction, feedback, Oller and Vigil (1976) declared that negative feedback can cause the student to stop interacting in the class, with the teacher and using the language. Oller and Vigil (1976) "Predominantly negative affective feedback whether expected or unexpected is likely to result in abortion of further communication attempts" (p.281). Taking this into consideration, the present study wants to research what type of correction affect students the most and if teachers can do something to reduce what students consider to be demotivating negative feedback.

\section{Error Classification}

In her article, Vázquez reflects on the errors through a communicative perspective (Vázquez, 2010, p. 168), since they can affect the comprehension of an oral or written message. Within them, the author selects three criteria of categorization - ambiguity, irritation and stigmatization. All these three elements are subjective to the listener, thus factors as the experience or the relation with the studied language can vary the degree of irritability the interlocutor experiences with the error.

The present study uses Vázquez’s (1991, 1999, 2010) ideas on error classification. Errors are classified by Vázquez into five criteria - grammatical, descriptive, pedagogic, etiological and communicative. The criteria descriptive and communicative are the ones used in the creation of the observation instrument for this research, the rubric. The rest of the criteria were excluded since to classify an error within those parameters, the researcher would need more time, knowledge on the area and carry out a lengthier study.

For all these categories Vázquez (2015) offers a list of possible corrective strategies that the teacher can implement. For example, correcting only the error related to the student's level, 
prepare a calendar with frequent errors for each learning stage, identify and correct "false friends" and teach students to comprehend meaning through context. Furthermore, there is a fundamental factor when deciding the type of correction, which is the level of seriousness. Vázquez (1999) explain that this concept is subjective, and that teacher should be careful to avoid situations of injustice.

\section{Types of Error Corrections (Feedback)}

Barbero Carcedo $(2008,2012)$ carried out a research on advantages and disadvantages of the use of different types of correcting techniques: techniques in which the student is interrupted and the solution is not given (IN), techniques in which the student is interrupted and the solution is given (IS), techniques in which the students is not interrupted and the solution is not given (NIN), and techniques in which the students is not interrupted and the solution is given (NIS). In her 2012 paper, Barbero presents teachers' preferred correction techniques. Most teachers favor techniques in which the student's error is highlighted but the answer is not given (NIN \& IN), this allows students to reflect on their output and self-assess. Furthermore, a limited number of teachers chose techniques in which the student is interrupted as a necessity, since they help fix errors immediately and prevent fossilizations.

After creating these types of corrections, Barbero Carcedo (2008) decided to test them doing some observations in the classroom. The author's conclusions were that the right type of correction changed depending on the activity done in class. Students preference changes, thus there is no general answer to what is the perfect type of correction.

[...] un alto porcentaje de los alumnos señalan como preferidas aquellas en las que se les llama la atención sobre un error pero se les ofrece la oportunidad de encontrar la forma 
correcta. $[\ldots]$ Otros estudiantes han seleccionado las formas de corrección en las que no se les interrumpe cuando están hablando como sus favoritas. (Barbero Carcedo, 2008, p. 27)

\section{Demotivation research on ESL context}

Articles like Kim and Kim (2013) offer a compilation of works of the last years on demotivation. The paper classifies studies as quantitative, qualitative and mix. Out of the 27 analyzed studies, 16 of them were quantitative, 5 qualitative and 6 mixed. This division shows the lack of qualitative studies, due to their difficult and expensive composition. Although Kim and Kim (2013) focuses on researches with English as a Second Language, it does comment on the need of more studies that use another language as the language of study. "As a matter of fact, all of the studies found focused on English learners in the EFL countries except for a study by Ushioda (1998) on Irish learners of French" (Kim \& Kim, 2013, p.78). Thus fore, it is considered necessary for there to be more studies focused on the acquisition of Spanish as a Foreign Language, since only some results from researches on English as the language of study can be used and implemented in the classroom.

In terms of compilations on corrective feedback, the work of Nassaji and Katachava (2017) is worth mentioning. These authors offer a selection of eleven informative articles classified by the setting corrections take place in - oral, with the computer, written and the teacher-student problems. The information from this article does not involve only one second language, making it easier for standards to be generalized to any second language classroom.

In 2004, Falout and Maruyama carried out a comparative study between students' language proficiency and their level of demotivation. For their study they used the nine demotivating factors presented by Dörnyei (2001) - the professor, inadequate school facilities, reduce self-confidence, 
negative attitudes towards the L2, the mandatory nature of the L2 study, interferences with other studied foreign language, negative attitudes towards the L2 community, attitude of the group members and the class book. In this study, the researchers created their own questionnaire, with 49 items, to discover the order of demotivation of Dörnyei's 9 factors in their 164 Japanese English-language learners. The final result showed a huge different between low and high proficiency students. Double the number of low-proficiency students disliked studying English, their demotivation started in junior high school, and is linked to their present affective state. On the contrary, high-proficiency students had more control over their affect state in the learning context. One factor identical with students of both proficiencies was their dislike for humiliating pedagogies, those which point out the lack of knowledge of the student.

In summary, most studies on students' demotivation are directed to learners of English as a Second Language. Due to the lack of diversity, it is difficult to generalize the results of previous studies on demotivation; therefore, it is important to develop more researches on languages that are not English.

\section{Methodology}

\section{Research process}

The study took place at the University of Hawai'i at Manoa during the semester of Spring 2020. The institution offers low and intermediate level classes of Spanish: SPAN 101 - Elementary Spanish I, 102 - Elementary Spanish II, 201 - Intermediate Spanish I and 202 - Intermediate Spanish II. For this study, four lectures, one at each level, were observed.

In total 4 courses were observed, with an average of 20 students per class. All classes follow the same textbook (Gente, De la Fuente, Martín and Sans, 2015- Pearson) including its online 
platform with the same task-based methodology as the book. The role of the teachers in these classes is that of a guide that helps students acquire knowledge and language proficiency.

\section{Participants}

All students that were present the day of the observations gave consent for their voice to be recorded during the class period, 50 minutes, and completed a survey, either in its online or paper version. In addition to collecting data from students, the different corrective feedback methods used by the teachers were recorded and analyzed following Barbero Carcedo's (2008, 2012) feedback types and Vázquez's (1991) error classification. The total number of participants were 4 lecturers and 63 students (16 in SPAN 101, 13 in SPAN 102, 19 in SPAN 201 and 15 in SPAN 202).

\section{Implementation}

A pilot study was conducted to analyze the relationship between error correction and the demotivation of students of Spanish as a Second Language in Spain. 67 students of Spanish in an intermediate level were the participants throughout a period of 3 weeks. The results of the pilot study showed that students prefer positive and constructive feedback and reject critical or judgmental feedback. Learners have difficulties perceiving NIN corrective style feedback, as they are also less motivated with indirect feedback styles (IN and NIN). Participants considered NIS (No Interruption and Solution) as the most motivating feedback, teachers offer a clear correction and give students enough time to self-assess themselves.

Based on the new possibilities of study, the pilot study's questionnaires were adapted to the new context and to better answer the research questions of this paper. The adaptations included 
a better translation to English and the combination of the two surveys from the pilot study into one.

\section{Data collection}

To capture and precisely describe how the correction is given and the non-verbal reactions of the teacher, the lesson was video recorded; an observation rubric based on Váquez's classification of errors was also used by the researcher to classify the corrections made in the classroom; in addition, a post-observation questionnaire was given to student-participants to complete post-lecture.

A camera was set at the end or the middle of the classroom, depending on the room's size, recording the audio and image of the teacher and only students' voices. It was necessary to videorecord the teacher, being that certain corrective feedback styles are present not only through verbal output, but also with non-verbal actions - body and facial gestures. The previously mentioned rubric (see Appendix 1) was also used during the whole observation to take note on the type of error corrected by the teacher, and what method did the instructor use to correct students' mistakes. Beside the counting of errors, the exact minute these took place was also annotated to facilitate the transcription of the session.

The post-observation questionnaire (see Appendix 2) was completed online and took students an average of 5-10 minutes to answer. The questionnaire, written in English, is split in four background questions - Languages you have studied, For how long have you studied each language?, What is your motivation to learn Spanish? and Why are you learning Spanish?. Following there are six questions about corrective feedback and how do students feel after receiving it - What does corrective feedback mean to you?, How comfortable do you feel when 
your teacher corrects you in the classroom?, Name or define the type of corrective feedback you like to receive the LEAST/MOST in the classroom. The survey finishes with 11 questions, most of which are Likert-scale, on the correction students' received that day in class, and follows with two open-ended questions, one of which was optional - Do you think the corrective feedback had something to do with your feelings/motivation today? Why?; Do you want to comment on anything from today's class or corrections?.

The data obtained from the Likert-scale and the observations was analyzed through descriptive statistics such as the mean, comparing also the relationship between correlated data, students' perceptions against the researcher's observations and recordings of the types of corrections done in class. A topic analysis was done for the open-ended questions', using Antconc (2019) as a tool to create a list of frequency words.

\section{Results}

The research questions analyzed in this study focus on students' demotivation and teacher correction. Making use of the questionnaire, that collects data of student's preferences and perceptions on the types of corrections, the video recordings, and the rubric with notes on the types of correction delivered in each class, we will try to answer the following three main research questions.

RQ1 - What types of oral corrective feedback really take place in a language class?

RQ2 - What type of oral corrective feedback is considered by students and teachers as the most motivating, demotivating and useful when learning a language?

RQ3 - Is there any relationship between second language proficiency and students' perception of oral corrective feedback? 
Before the data collection took place, possible results were hypothesized using the researcher's previous pilot study and Barbero Cardedo's (2012) teachers' preferred correction types as a base. For research question 1, a great amount of correction types IS (interruption and solution) and NIS (no-interruption and solution) were expected. Previous studies showed students preference for corrections in which teachers gave them the answers directly getting instant feedback. The obtained data confirms this idea since out of the 46 total corrections only 5 were IN and NIN, NIS was used a total of 29 times (63.04\% of the time) and IS was used 12 times (26.09\%).

For research question 2 - the type of corrective feedback considered by students as most (de)motivating and useful when learning, the corrections type IN (interruption but no solution) and NIN (no-interruption and no solution) were considered to be demotivating since these might confuse lower level students. The obtained data favored the hypothesis since IN and NIN received the lowest grade on the Likert-scale (2.62 and 3.05) in every class. Furthermore, through the openended questions participants described the least motivating corrections as those that call out on the students, give no explanation and have negative connotations or words ("no", "wrong", humiliating). Meanwhile the most motivating corrections are those that are given orally, fix pronunciation, given individually and are direct, students favoring words like "Close" or "Not quite".

Finally, for research question 3, correlation between language proficiency and perceptions of error correction, it was expected for students in lower levels to show more comfort with error correction since they have no expectations or experiences to compare with, and for higher level students to be more conscious of the teacher corrections due to their good understanding of the language. The research shows that students' comfort with error correction slightly decreases the 
higher is their language proficiency; however, lower proficiency perceive less corrections than their higher level counterparts.

\section{Research Question 1}

The observed sessions and completed questionnaires helped discover what types of corrections might (de)motivate students, and if there's any difference within diverse language proficiencies.

Figure 1 illustrates a comparison of the different types of corrections present in the total of the session. Out of the 46 observed corrections, only $1(2.17 \%)$ was IN (interruption but no solution); $4(8.70 \%)$ were NIN (no-interruption and no solution); $12(26.09 \%)$ were IS (interruption and solution) and $29(63.04 \%)$ were NIS (no-interruption and solution). This confirms the hypothesis for research question 1 and Barbero Carcedo's (2012) results on teacher preference, that the type of correction in which the teacher gives the solution cutting students during their speech (IS) or after they finished speaking or at the end of the lesson (NIS) are the most common in the language class. Offering an immediate solution allows teachers to pick up the pace when teaching and solves instantly and directly any question students might have (Barbero Carcedo, 2012). 


\section{Figure 1}

Total type of corrections observed by the researcher

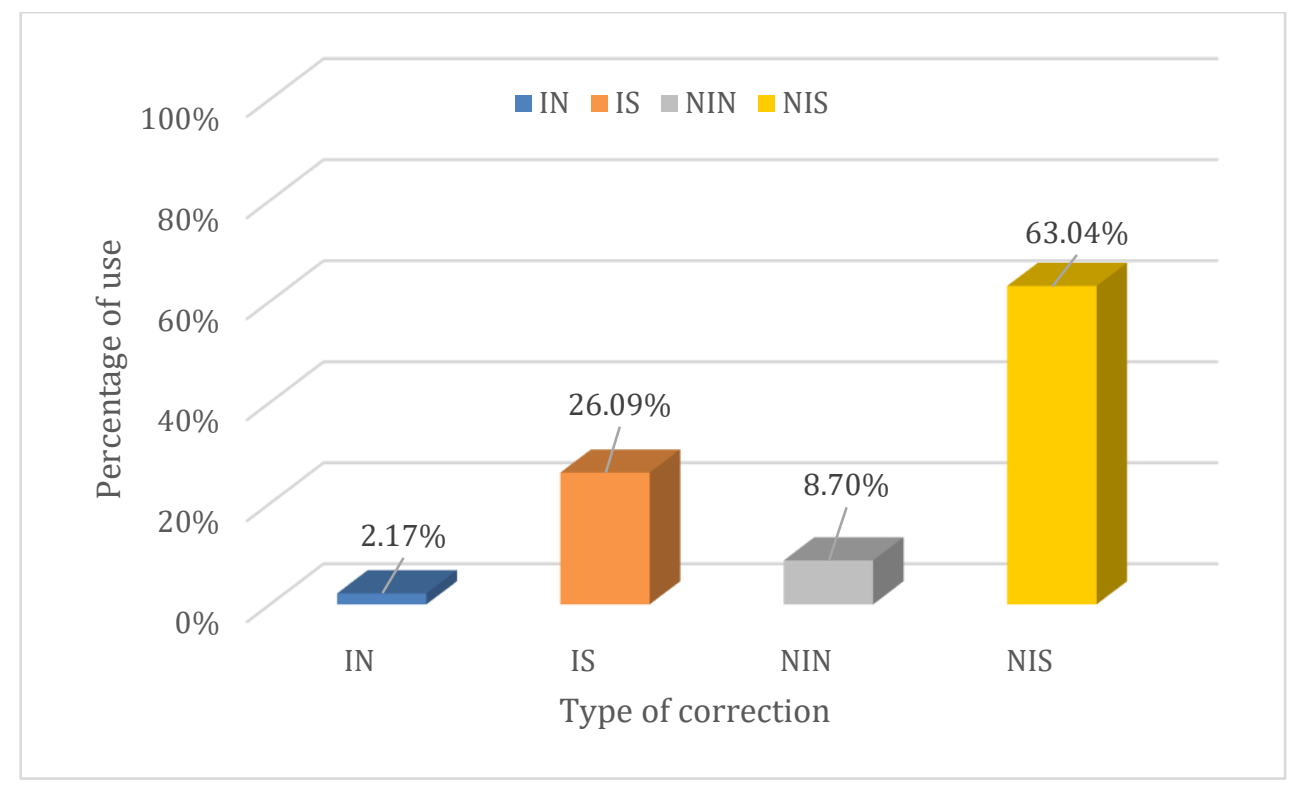

\section{Table 1}

Total type of corrections observed by the researcher

\begin{tabular}{|c|c|c|c|c|c|}
\hline & IN & IS & NIN & NIS & TOTAL \\
\hline $\begin{array}{c}\mathrm{N}^{\mathrm{o}} \text { of } \\
\text { corrections }\end{array}$ & 1 & 12 & 4 & 29 & $\mathbf{4 6}$ \\
\hline $\begin{array}{c}\text { Percentage of } \\
\text { appearance }\end{array}$ & $2.17 \%$ & $26.09 \%$ & $8.70 \%$ & $63.04 \%$ & $100 \%$ \\
\hline
\end{tabular}

Examples of the different types of corrections observed and recorded are:

IN (Interruption and No Solution) - the whole class of 201 was doing an activity in which they would create all together a famous persons' biography. When the turn came, a student started the sentence with "Empiezó", the teacher instantly repeated the word (echoed) with a rising interrogative intonation and looked at the whole class changing his facial gesture to show that the 
word wasn't right. The whole class instantly saw the mistake and corrected the answers saying "Empezó". When the right answer was given, the teacher offered a smile to the students.

IS (Interruption and Solution) - while a pair of students in the 202 class were doing an impromptu speech on renting a house, one of the participants said "no tengo una mascoto" after which the teacher cut in and corrected with "mascota".

NIN (No Interruption and No Solution) - the class of 201 was adapting and text and its verbs from the third person to the first person. When they had to conjugate the verb "casarse" to first person future tense, students gave answers like "se casó" and "se casaste", after which the teacher changed his facial gestures, raised his eyebrows and positioned his hand in his chin suggesting a thinking face. With this changes in gestures, students noticed there was a mistake with their answers and corrected themselves saying "me casé".

NIS (No Interruption and Solution) - the class of 101 was going through an activity of matching verbs with actions. When the topic of Facebook came out, one student said "soy" as in "to be", however, in Spanish the right answer would come from the verb "estar" which also means "to be". The teacher waited for the student to finish the sentence and corrected the student stating that the right verb would be "estoy" and gave a brief explanation.

Another example of NIS correction would be when a pair of students of the 202 class was doing a speech on renting a house and one of the students said "un habitación no muy caro", after which the teacher wrote on the board "habitación cara", giving the student feedback on the gender of the word "habitación" and how there should be a match in gender between nouns and their adjectives. 


\section{Research Question 2}

Answering research question 2, type of corrective feedback considered by students as most (de)motivating and useful when learning, Figure 2 shows students' opinions on the different types of correction (IN, IS, NIN and NIS) and which ones do they consider as motivation; this was answered through a Likert Scale question (1 - not motivated; 5 - very motivated). The data confirms the hypothesis that corrections IN and NIN are considered to be the least motivating, even through different proficiency levels. IN and NIN were considered as somewhat by students of SPAN 201, receiving grades of 3.11 and 3.42 out of 5; however, the mean of 2.62 out of 5 for IN presents this as the least motivating. Through all the levels of proficiency, NIS was considered the most motivating type of correction, never going lower than 4.56, followed by IS, although this had a lower average of 3.5 and was never considered as "fully motivating" since it was below 4.00.

\section{Figure 2}

Students' opinion on motivation with each type of correction

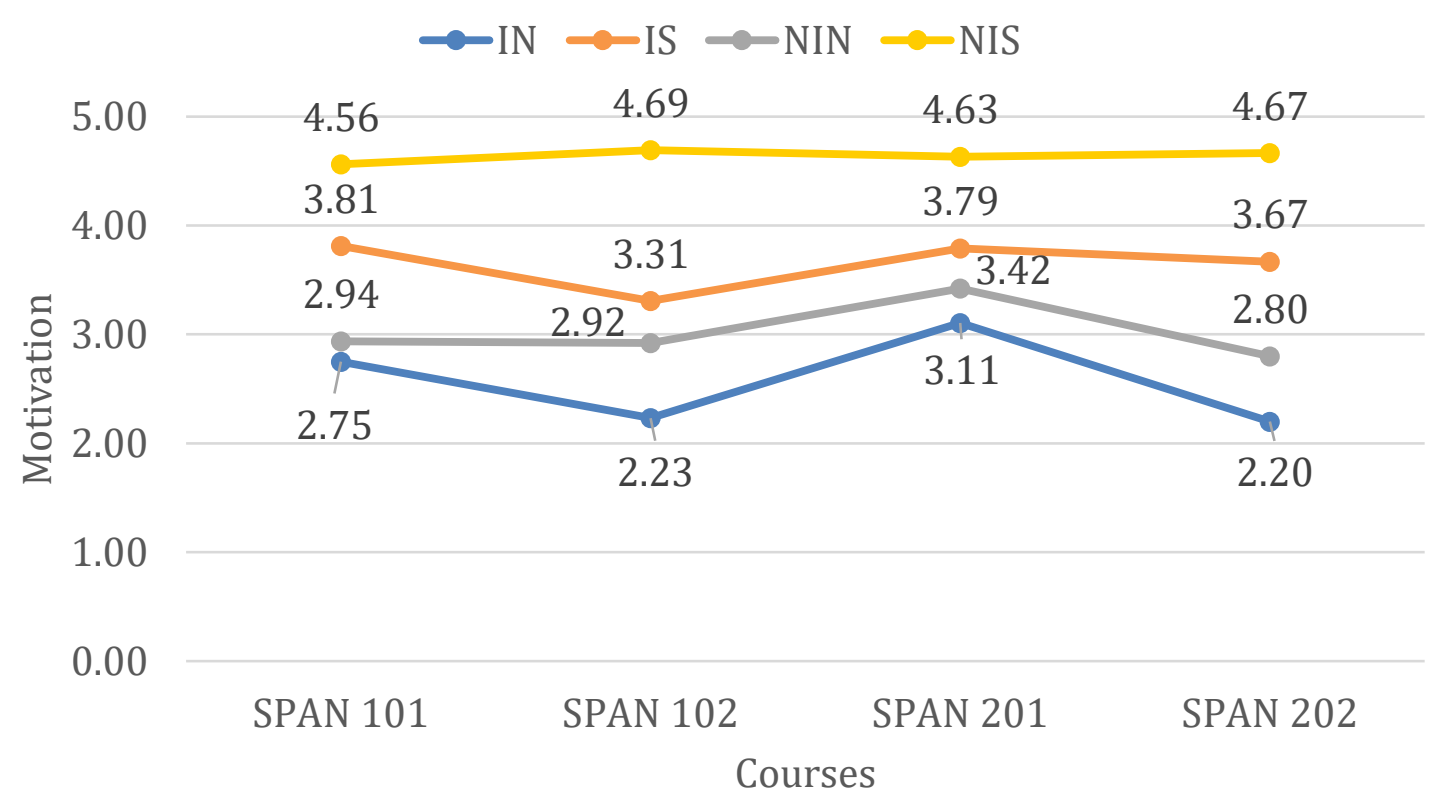




\section{Table 2}

Students' opinion on motivation with each type of correction

\begin{tabular}{|l|c|c|c|c|c|}
\hline & SPAN 101 & SPAN 102 & SPAN 201 & SPAN 202 & Mean \\
\hline IN & 2.75 & 2.23 & 3.11 & 2.20 & 2.62 \\
\hline IS & 3.81 & 3.31 & 3.79 & 3.67 & 3.67 \\
\hline NIN & 2.94 & 2.92 & 3.42 & 2.80 & 3.05 \\
\hline NIS & 4.56 & 4.69 & 4.63 & 4.67 & 4.63 \\
\hline
\end{tabular}

Note: Likert scale answers. 1 - Not motivating at all, 5 - Very motivating.

When asked about how comfortable students are with getting corrected in the classroom, the study showed that students' comfort with error correction has a slight tendency to decrease the higher their proficiency. Low proficiency class students, SPAN 101, are fully comfortable with getting corrected by the teacher (4.75 out of 5); while higher level students, SPAN 202, are slightly less comfortable (4.13 out of 5). Even though all answers are over 4 in the Likert-scale, which means students are comfortable with being corrected; the light change between the courses, brings to question if higher level students are more uncomfortable and what could be the possible causes of this feeling. SPAN 201 students do not follow the tendency, being more comfortable than SPAN 102, this could be related to the great amount of participation in the higher level and the class setup of a U-shape which promotes more class participation than rows and column setting (Rocca, 2010), being this last setup the one in SPAN 102. 


\section{Figure 3}

Student comfort with error correction

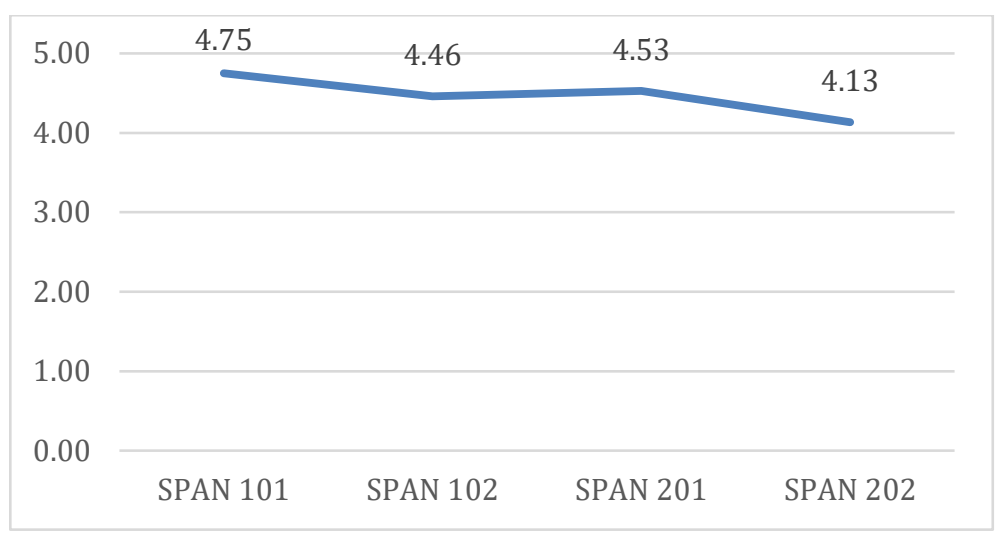

To try and answer the question on what produces students' discomfort when being corrected, the questionnaire offered two open-ended questions about the types of corrections students found the most or least motivating. Table 3 presents a list of frequency words that students used the most when describing the types of correction that motivated them the least and the most. The list represents instances of that word in the totality of students' answers to the open-ended questions "Name or define the type of corrective feedback you like to receive the LEAST/MOST in the classroom" in the questionnaire. The general answer to the questions showed students felt the least motivated when put on the spot or called out in front of the class. Mentions to negative feedback or the teacher saying "no" with or without a right answer following the word, are also present as some of the least motivating and liked feedback. When asked on the survey about the feedback that motivated students the most, there was a general reference to positive oral constructive feedback (grammar and pronunciation); some students prefer an individual correction, however, one of the most important factors seems to be the teacher's attitude when correcting (smiling, positive, calm tone of voice, etc). 
Table 3

\begin{tabular}{|c|c|c|c|}
\hline \multicolumn{2}{|c|}{ LEAST MOTIVATING CORRECTIONS } & \multicolumn{2}{|c|}{ MOST MOTIVATING CORRECTIONS } \\
\hline Instances & Comments & Instances & Comments \\
\hline 4 & Called out/on & 11 & Oral / Orally / Verbal \\
\hline 4 & $\begin{array}{l}\text { No correction/ explanation/ } \\
\text { criticism / help }\end{array}$ & 5 & Grammar \\
\hline 3 & $\begin{array}{l}\text { In front of the class/ everyone/ } \\
\text { a bunch of people }\end{array}$ & 5 & Pronunciation / Pronounce \\
\hline 3 & Saying something is "wrong" & 3 & Written \\
\hline 3 & Written & 3 & In class \\
\hline 3 & $\begin{array}{l}\text { Embarrassing / embarrassment } \\
\text { / Humiliating }\end{array}$ & 3 & $\begin{array}{l}\text { Individual feedback / being } \\
\text { pulled aside / } 1 \text { on } 1\end{array}$ \\
\hline 2 & No & 3 & All feedback \\
\hline 2 & Negative feedback & 2 & Constructive \\
\hline 2 & Puts you / say on the spot & 2 & Group \\
\hline 2 & Direct & 2 & "Close" or "not quite" \\
\hline 2 & $\begin{array}{l}\text { Feedback from peers / other } \\
\text { students }\end{array}$ & 2 & $\begin{array}{l}\text { Direct / Correcting } \\
\text { automatically }\end{array}$ \\
\hline 2 & Nothing / none & 2 & Calm / gentle \\
\hline 2 & Shouting / yelling & 1 & Positive feedback \\
\hline 1 & Negative experience & 1 & Guiding feedback \\
\hline 1 & Orally & 1 & Helpful feedback \\
\hline & & 1 & Corrective feedback \\
\hline
\end{tabular}

Figure 4 below offers detailed information, obtained through the rubric and the review of the recordings, on the types of correction present in each course by percentage of use. Corrections IN and NIN are present the least, with IN being used only once in SPAN 201 and NIN being used two times in SPAN 201 and once in SPAN 101 and 202. The correction NIS is used over 50\% of the times in all levels, reaching an $80 \%$ and $70.59 \%$ of use in SPAN 201 and 202. In summary, this shows that the most used type of correction, NIS, is also the one considered the most motivating by students, Figure 2 . 


\section{Figure 4}

Types of correction observed by the researcher

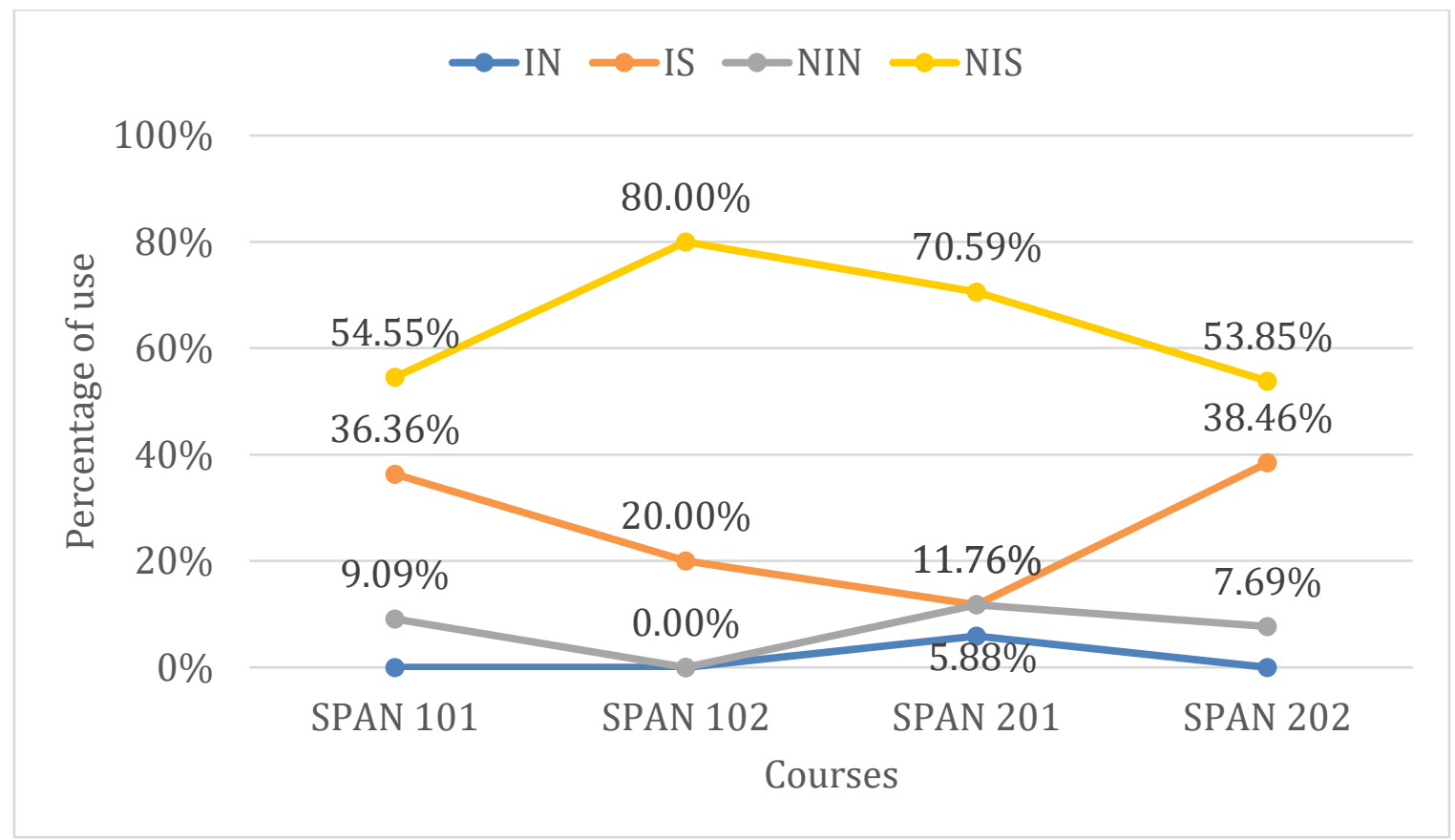

\section{Table 4}

Types of correction observed by the researcher

\begin{tabular}{|c|c|c|c|c|c|}
\hline & SPAN 101 & SPAN 102 & SPAN 201 & SPAN 202 \\
\hline \multicolumn{2}{|c|}{$\begin{array}{l}\text { Total corrections per } \\
\text { session }\end{array}$} & 11 & 5 & 17 & 13 \\
\hline \multirow[b]{2}{*}{ IN } & $\%$ & $0.00 \%$ & $0.00 \%$ & $5.88 \%$ & $0.00 \%$ \\
\hline & $\begin{array}{c}\mathrm{N}^{\mathrm{o}} \text { of } \\
\text { corrections }\end{array}$ & 0 & 0 & 1 & 0 \\
\hline \multirow[b]{2}{*}{ IS } & $\%$ & $36.36 \%$ & $20.00 \%$ & $11.76 \%$ & $38.46 \%$ \\
\hline & $\begin{array}{c}\mathrm{N}^{\mathrm{o}} \text { of } \\
\text { corrections }\end{array}$ & 4 & 1 & 2 & 5 \\
\hline$\overline{\mathrm{NIN}}$ & $\%$ & $9.09 \%$ & $0.00 \%$ & $11.76 \%$ & $7.69 \%$ \\
\hline
\end{tabular}




\begin{tabular}{|c|c|c|c|c|c|}
\hline & $\begin{array}{c}\mathrm{N}^{\circ} \text { of } \\
\text { corrections }\end{array}$ & 1 & 0 & 2 & 1 \\
\hline \multirow{2}{*}{ NIS } & $\%$ & $54.55 \%$ & $80.00 \%$ & $70.59 \%$ & $53.85 \%$ \\
\cline { 2 - 6 } & $\begin{array}{c}\mathrm{N}^{\circ} \text { of } \\
\text { corrections }\end{array}$ & 6 & 4 & 12 & 7 \\
\hline
\end{tabular}

\section{Research Question 3}

To answer research question 3, relation between language proficiency and perceptions of error correction, we have to compare the data from four questions in the questionnaire that asked students to select how many times they have perceived each type of correction during the whole session. Students' possible answers were amount of percentages $(0-20 \%, 20-40 \%, 40-60 \%, 60-$ $80 \%$ and $80-100 \%)$.

\section{Figure 5}

Types of correction perceived by students - Proficiency Difference

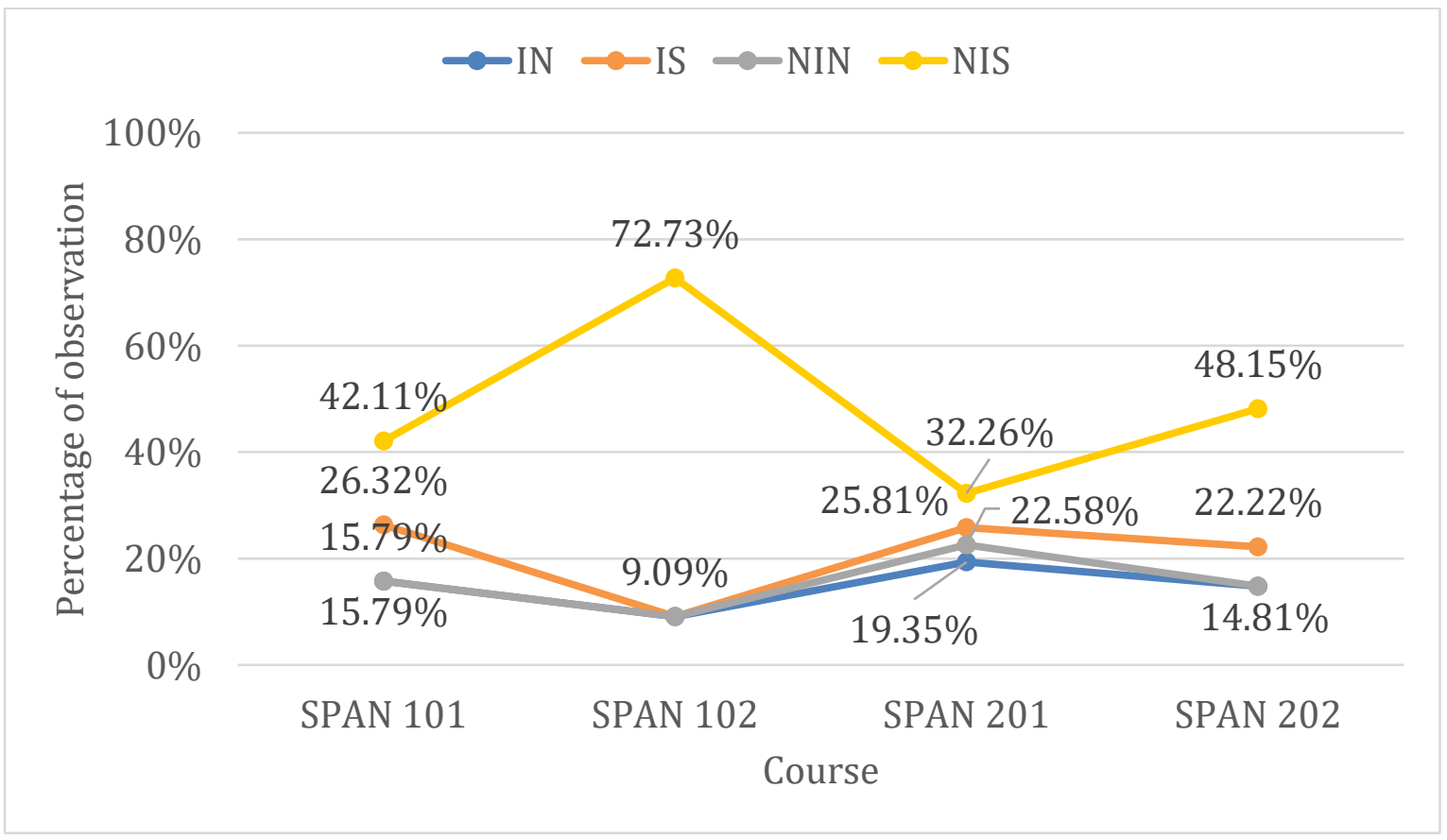




\section{Table 5}

Types of correction perceived by students - Proficiency Difference

\begin{tabular}{|c|c|c|c|c|}
\hline & SPAN 101 & SPAN 102 & SPAN 201 & SPAN 202 \\
\hline IN & $15.79 \%$ & $9.09 \%$ & $19.35 \%$ & $14.81 \%$ \\
\hline IS & $26.32 \%$ & $9.09 \%$ & $25.81 \%$ & $22.22 \%$ \\
\hline NIN & $15.79 \%$ & $9.09 \%$ & $22.58 \%$ & $14.81 \%$ \\
\hline NIS & $42.11 \%$ & $72.73 \%$ & $32.26 \%$ & $48.15 \%$ \\
\hline
\end{tabular}

In SPAN 101, students seem perceive slightly less corrections done by the teacher than the researcher. Students missed $11.44 \%$ of the NIS and $10.04 \%$ of the NIS feedback provided by the teacher, while they also said to have perceived IN and NIN corrections when there were none. SPAN 102 students seem to perceive NIS the most (72.73\%), similar to the amount observed by the researcher (80\%), however, the rest of the correction types (IS, NIN \& IN) were missed by the students and are classified as present $9.09 \%$ of the times, which does not match the results found by the researcher. SPAN 201 students seem to perceive NIS the least $32.26 \%$ out of every other course, which compare to the $70.59 \%$ in Figure 4 shows there is an element of confusion - students might not actively perceive this type of correction, and the more students understand the language the more sensitive are they to interruptions in their speech. Finally, SPAN 202 students seem to have perceived IS $(22.22 \%)$ less than the researcher, which could have been caused by the teacher writing down most of the corrections on the board letting students speak instead of stopping them mid-sentence to correct the learners.

\section{Discussion and Conclusions}

The observations and questionnaires offered the possibility of better comprehending students' reactions when being corrected and their predilections for certain type of correction. 
Positive oral feedback that helps improve students' knowledge of the language seems to be preferred. Direct solutions by the teacher are also looked at favorably, since they usually come with an explanation. Now, how should teachers implement these discoveries in their teaching?

When asked, in the questionnaires, about the type of feedback they like the most or the least, students rarely made any mention to the time at which they were corrected, whether instant or after they finish speaking; however, they did point out how teachers correct students, what words were they least comfortable hearing ("No", "Wrong") the tone of voice they liked the least (shouting, humiliating), elements of the their speech they wanted to be corrected on (pronunciation, grammar), words they preferred to hear when being corrected ("close" "not quite") preferred teacher attitude when giving feedback (positive, guiding, helpful, calm, gentle) and how the teacher should give feedback (not calling out students in front of the class or putting them on the spot, but doing individual feedback and pulling students aside). Some students mentioned not having any predilection for certain types of correction, and some reported disliking corrective feedback, however, they are aware of the importance of this type of feedback for their language proficiency, even if it is demotivating.

Taking students' opinions in consideration, it is recommended for teachers to start the semester asking students for their strengths and weaknesses in the language and their preferences when being corrected. A consensus should be reached to better guide teachers through the corrective process, and help students become more comfortable with receiving feedback, helping transform the classroom into a safe space in which students are comfortable to speak and learn.

When thinking about types of correction, teachers should also be aware of students' perceptions. Feedback which gives the solution (IS and NIS) is better perceived by students and also by teachers (Barbero Carcedo, 2012). Getting a direct solution and an explanation is preferred 
by students, being that they still remember the sentence they made and can note down the corrections automatically. The higher the proficiency the more students seem to also like immediate corrections without solution (IN). Lyster and Ranta's (1997) also show through their data that students actively participate more when there is negotiation of form and the answer is not given; therefore, corrections type IN and NIN do have extra benefits in the classroom, even if not motivating in lower levels.

Even though not conclusive, this study shows a relation between types of correction and motivation. To better understand how these corrections affect students' development, another study with a wider range of language proficiency students should be done. It is recommended for future studies to first introduce the terms of the types of correction studied and give examples, so there are no possible misconceptions, and for the researchers to elaborate a longitudinal research, to control any possible limiting factors such as intrinsic and extrinsic motivation. 


\section{References}

Anthony, L. (2019). AntConc (Version 3.5.8) [Computer Software]. Tokyo, Japan: Waseda University. https://www.laurenceanthony.net/software

Arnold, J. (Ed.). (2000). La dimensión afectiva en el aprendizaje de idiomas. Madrid: Cambridge University Press.

Barbero Carcedo, V. (2009). ¿Cómo acertar en la corrección?: ventajas e inconvenientes de las técnicas de corrección de errores en la expresión oral. (Master Thesis). Instituto Cervantes - Universidad Internacional Menéndez Pelayo.

Barbero Carcedo, V. (2012). ¿Cómo acertar en la corrección?: Ventajas e inconvenientes de las técnicas de corrección de errores en la expresión oral. Boletín de la Asociación para la Enseñanza del Español como Lengua Extranjera, 46, 17-30. http://www.aselered.org/sites/default/files/boletines/ASELE\%2046.pdf

Dörnyei, Z. (2001). Teaching and researching motivation. Harlow: Pearson Education.

Dörneyi, Z y Ushioda E. (2011). Teaching and researching motivation. Nueva York: Taylor \& Francis.

Falout, J. y Maruyama, M. (2004). A comparative study of proficiency and learner demotivation. The Language Teacher, 28(8), 3-9. https://jaltpublications.org/tlt/articles/447-comparative-study-proficiency-and-learner-demotivation

Kikuchi, K. (2015). Demotivation in second language acquisition: Insights from japan. Bristol: Multilingual Matters. 
Kim, Y.K. y Kim, T.Y. (2013). English learning demotivation studies in the EFL contexts: State of the art. Modern English Education, 14(1), 77-102.

Krashen, S. (1982). Principles and Practice in Second Language Acquisition. http://www.sdkrashen.com/content/books/principles_and_practice.pdf

Lamb, M. (2011). Future selves, motivation and autonomy in long-term EFL learning trajectories. In G. Murray, X. Gao, \& T. Lamb (Eds.), Identity, motivation and autonomy in language learning (pp.177-194). Tonawanda, NY: Multilingual Matters.

Lyster, R. \& Ranta, L. (1997). Corrective feedback and learner uptake: Negotiation of form in communicative classrooms. Studies in Second Language Acquisition, 19, 37-66.

Nassaji, H. y Kartchava, E. (Eds.). (2017). Corrective feedback in Second Language Teaching and Learning - Research, theory, applications, implications. Nueva York: Taylor \& Francis.

Oller, J. y Vigil, N. (1976). Rule fossilization: a tentative model. Language learning a journal of research in language studies, 26(2), 281-295. https://doi.org/10.1111/j.14671770.1976.tb00278.x

Rocca, K. A. (2010) Student Participation in the College Classroom: An Extended Multidisciplinary Literature Review, Communication Education, 59(2), 185-213, DOI: $10.1080 / 03634520903505936$

Torijano, P. (2004). Errores de aprendizaje, aprendizaje de los errores. Madrid: Arco Libros.

Ushioda, E. (1996). Language learners' motivational thinking: a qualitative study. Doctoral Thesis, University of Dublin, Trinity College, Dublín. 
Ushioda, E. (1998). Effective motivational thinking: A cognitive theoretical approach to the study of language learning motivation. En E.A. Soler \& V.C. Espurz (Eds.), Current issues in English learning methodology (pp.77-89). Castelló de la Plana, España: Universitat Jaume I.

Vázquez, G. (1999). ¿Errores? ¡Sin falta! Madrid: Edelsa.

Vázquez, G. (2010). Hacia una valoración positiva del concepto del error. MarcoELE, 11, 164177. https://marcoele.com/descargas/navas/07.vazquez.pdf

Yong, Z., and Coates, K. (2016). Counting What Counts: Reframing Education Outcomes. Bloomington, IN: Solution Tree Press 


\section{Appendix A: Observation table}

\begin{tabular}{|c|c|c|c|c|c|c|}
\hline & & & SPAN 101 & SPAN 102 & SPAN 201 & SPAN 202 \\
\hline \multirow{16}{*}{ 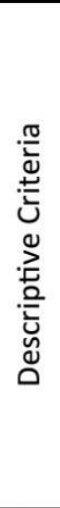 } & \multirow{4}{*}{ omission } & IN & & & & \\
\hline & & IS & & & & \\
\hline & & NIN & & & & \\
\hline & & NIS & & & & \\
\hline & \multirow{4}{*}{ addition } & IN & & & & \\
\hline & & IS & & & & \\
\hline & & NIN & & & & \\
\hline & & NIS & & & & \\
\hline & \multirow{4}{*}{$\begin{array}{c}\text { false (wrong) } \\
\text { choice }\end{array}$} & IN & & & & \\
\hline & & IS & & & & \\
\hline & & NIN & & & & \\
\hline & & NIS & & & & \\
\hline & \multirow{4}{*}{$\begin{array}{l}\text { false (wrong) } \\
\text { placement }\end{array}$} & IN & & & & \\
\hline & & IS & & & & \\
\hline & & NIN & & & & \\
\hline & & NIS & & & & \\
\hline \multirow{12}{*}{ 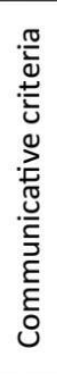 } & \multirow{4}{*}{ ambiguity } & IN & & & & \\
\hline & & IS & & & & \\
\hline & & NIN & & & & \\
\hline & & NIS & & & & \\
\hline & \multirow{4}{*}{ irritation } & IN & & & & \\
\hline & & IS & & & & \\
\hline & & NIN & & & & \\
\hline & & NIS & & & & \\
\hline & \multirow{4}{*}{ stigmatization } & IN & & & & \\
\hline & & IS & & & & \\
\hline & & NIN & & & & \\
\hline & & NIS & & & & \\
\hline & OBSERVATIONS & & & & & \\
\hline
\end{tabular}

LEGEND

IN Techniques in which students are interrupted and the solution is not given (to invite students to correct themselves)

IS Techniques in which students are interrupted and the solution is given

NIN Techniques in which students are not interrupted and the solution is not given

NIS $\mid$ Techniques in which students are not interrupted and the solution is given 


\section{Appendix B: Questionnaire}

\section{Corrective Feedback Survey \\ *Obligatorio}

1. Class *

Marca solo un óvalo.

$$
\begin{aligned}
& \text { SPAN } 101 \\
& \text { SPAN } 102 \\
& \text { SPAN } 201 \\
& \text { SPAN } 202
\end{aligned}
$$

\section{Languages you have studied *}

Selecciona todos los que correspondan.

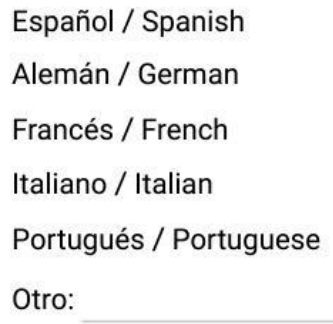

3. For how long have you studied each language? * Marca solo un óvalo por fila.

I have not studied this
language.
Español / Spanish
Alemán / German
Francés / French
Italiano /Italian
Portugués /
Portuguese
Otros / Other
languages

4. What is your motivation to learn Spanish? Why are you learning Spanish? * 
5. What does corrective feedback mean to you?

6. How comfortable do you feel when your teacher corrects you in the classroom? * Marca solo un óvalo.

Not comfortable at all

7. Do you think correcting in class is useful? * Marca solo un óvalo.
$\begin{array}{lllll}1 & 2 & 3 & 4 & 5\end{array}$

Not useful at all $\square \square \square(\square+\square$ Really useful

8. Do you learn when your teacher corrects you orally in the classroom? * Marca solo un óvalo.

$\begin{array}{lllll}1 & 2 & 3 & 4 & 5\end{array}$

Not at all $\square \longrightarrow \bigcirc \bigcirc$ A lot

9. Name or define the type of corrective feedback you like to receive the LEAST in the classroom. *

10. Name or define the type of corrective feedback you like to receive the MOST in the classroom. * 
11. From 1-5, point how motivated you felt today in the classroom. *

Marca solo un óvalo.

$\begin{array}{lllll}1 & 2 & 3 & 4 & 5\end{array}$

Not motivated at all $\square \longrightarrow C$ Really motivated

12. Do you think the corrective feedback had something to do with your feelings/motivation today? Why? *

13. Case 1: The teacher corrects you while you are speaking, warning you about an error in your discourse, without giving you the correct answer. How motivated would you feel later to use the language (Spanish)? *

Marca solo un óvalo.

Not motivated at all $\square$

14. Case 2: The teacher corrects you while you are speaking, interrupting you and giving you the answer. How motivated would you feel later to use the language (Spanish)? *

Marca solo un óvalo.

$\begin{array}{lllll}1 & 2 & 3 & 4 & 5\end{array}$

Not motivated at all $\square \longrightarrow C$ Really motivated

15. Case 3: The teacher corrects you after you finish speaking, warning you about an error in your discourse, without giving you the correct answer. How motivated would you feel later to use the language (Spanish)? *

Marca solo un óvalo.

$\begin{array}{lllll}1 & 2 & 3 & 4 & 5\end{array}$

Not motivated at all

$\square \bigcirc \bigcirc \bigcirc$ Really motivated

16. Case 4: The teacher corrects you after you finish speaking, giving you the correct answer. How motivated would you feel later to use the language (Spanish)? *

Marca solo un óvalo.

$\begin{array}{lllll}1 & 2 & 3 & 4 & 5\end{array}$

Not motivated at all $\square \longrightarrow \square$ Really motivated 
17. From 1-5, how much does correction in the classroom inhibit you to use the language? * Marca solo un óvalo.

Does not affect me

18. What corrections have you seen today in the classroom? *

Selecciona todos los que correspondan.

$\square$ IN - Case 1
$\square \quad$ IS - Case 2
$\square \quad$ NIN - Case 3
$\square$ NIS - Case 4
$\square \quad$ Neither

19. What percentage of each type of correction have you seen today? Marca solo un óvalo por fila.

IN - Case 1

20. From 1-5, point how much does each type of correction motivate you. * Marca solo un óvalo por fila.

$\begin{gathered}1 \text { - It does not } \\ \text { motivate me }\end{gathered} \begin{gathered}2 \text { - It } \\ \text { motivates me } \\ \text { a bit }\end{gathered}$
IN - Case 1
IS - Case 2
NIN - Case 3

21. (OPTIONAL) Do you want to comment on anything from today's class or corrections? You can write anything you like here. 